\title{
THE CONCEPT OF GOVERNANCE IN THE SPIRIT OF CAPITALISM
}

\author{
Matthew Eagleton-Pierce \\ SOAS, University of London \\ Lecturer in International Political Economy \\ Email: m.eagleton-pierce@soas.ac.uk \\ Article published in: \\ Critical Policy Studies, 8 (2014), 1, 5-21.
}

\begin{abstract}
$\underline{\text { Abstract }}$
Through combining insights from political economy and sociology, this article explains the early genesis of the policy notion of governance in relation to ideological changes in capitalism. Such an approach has tended to be neglected in existing conceptual histories, in the process, undermining a sharper politicisation of the term and how it became normalised. The argument dissects how the emergence of governance can be understood in light of a relationship between political crises, social critique, and justificatory arguments (centred around security and justice claims) that form part of an ideological 'spirit of capitalism'. Through a distinctive comparison between the creation of 'corporate governance' in the 1970s and the formulation of a 'governance agenda' by the World Bank from the 1980s, the article elucidates how the concept, within certain policy uses, but by no means all, can reflect and help constitute a neoliberal spirit of capitalism.
\end{abstract}

Keywords

capitalism, corporate governance, governance, legitimation strategies, World Bank

Word count (including notes and bibliography):

9223 
There are few more challenging and enduring problems within critical theorising than explaining why the common sense makes political sense. To reconstruct the genesis of the everyday opinion can be at once intimately recognisable and strangely perplexing, above all because what passes as the conventional wisdom does not always appear as a problem. Clichés, commonplaces, and hackneyed expressions often circulate smoothly and rapidly. Gustave Flaubert, the nineteenth-century novelist who devoted considerable attention to the concept of authenticity whether in language or relationships, called such expressions the 'received ideas'. 'In many instances, by the time the idea has reached one person, it has already been received by others, so reception never seems to be a problem. Undoubtedly, one of the best examples of such a received idea in current parlance is 'governance'. In less than three decades, this word has re-emerged from its previously dormant status to be rethought and deployed across a range of domains and institutions, but often by actors who have different and contradictory ends. The term has been promoted as a central term of reference, either descriptively or normatively, and sometimes as both at once. 'Governances' are now multiplying at a remarkable rate, and can be found in all types of institutional settings and forums, from school governance and church governance to health governance and environmental governance. In corporate mission statements and annual reports few other words appear as attractive or necessary. At the same time, permeating policy communities and academic research agendas are the two major derivatives: global governance and good governance. In short, governance has become a remarkably accessible and flexible word. Indeed, it has become so flexible that different actors have been able to 'empty into' the term their own meanings and visions, from business executives wanting to secure intellectual property rights to charity workers wanting respect for human rights.

At first glance, one may query why another conceptual dissection of governance is needed. A considerable amount of ink in both the social sciences and the policy world has already been spilt on trying to isolate the meaning of this pervasive term. Nonetheless, despite the apparent intuitive appeal of the concept, this article argues that governance contains some very contentious social and political histories. The 'comet-like' rise of the notion is interesting not simply on etymological grounds, but also for how uses of the word illuminate larger struggles over the relationship between language and power in political life. ${ }^{2}$ However, in this article, I argue that part of the conceptual problem with governance lies in how its specific ideological relationship to capitalism has been underspecified. This is not to suggest, in any kind of crude sense, that the term has not been used to shed light on many political economy questions surrounding, for instance, the organisation of capitalist democracies or the world economy. Nor am I implying that all applications of the expression - academic or policy - are somehow intentionally infused with business motivations, that is, viewing ideology in the classic Marxist sense as a 'cloaking' device to obscure material interests. Rather, my aim here is empirically restricted to further problematising and, importantly, historicising the early genealogy of governance as a policy term. I suggest that understanding this history is best captured through a conceptual framework that is alert to the relationship between political

\footnotetext{
${ }^{1}$ Gustave Flaubert, The Dictionary of Accepted Ideas (New York: New Directions, 1968). The book was originally published posthumously in 1913 .

${ }^{2}$ Claus Offe, 'Governance: An “Empty Signifier”?', Constellations, 16 (2009), 4, 550-562, quoted at 550 .
} 
forces, social critique, and debates that are used to explain and, significantly, constitute, particular forms of capitalism.

My argument is organised into four sections. First, I provide an initial justification for the ambitions of the article, including attention to how governance has been commonly interpreted with reference to political economy issues. I also explain how my proposition that the concept can be read as an ideological expression of capitalist practice is shared by other writers. Second, the article explains the analytical framework that will be used for critically examining governance. Here, I draw upon the work of the sociologists Luc Boltanski and Ève Chiapello, who have constructed a sophisticated argument around explaining how ideological practices associated with neoliberalism form part of the latest 'spirit of capitalism'. ${ }^{3}$ I briefly outline what constitutes this spirit and, in particular, stress how capitalism always requires arguments that answer, or appear to answer, enduring questions of security and justice. The third and fourth sections form the empirical tracing of the concept which is, in large part, a US-based story. The argument begins by situating the emergence of the term in the 1970s in light of the broader crisis of governability. Through a novel comparison between the formation of 'corporate governance' and, by the 1980s, the appropriation of a 'governance agenda' by the World Bank, my argument aims to elucidate how this term, within certain policy uses, can reflect and help legitimise a neoliberal spirit of capitalism. Thus, the paper considers how the word could be considered a fruitful entrée into analysing a number of core political enquires, including macro shifts in the evolution of the economy, the management of social critique and, in general, methods of legitimation deployed within power relations.

\section{I. 'GOVERNANCE' AND ITS DISCONTENTS}

Within political science, public policy, and international relations, there remains considerable debate over what phenomena should be classified under the heading of governance and how the term enhances our understanding of the political world. ${ }^{4}$ Indeed, for some, the very ubiquity and 'stretching' of the concept risks devaluing whatever utility it might potentially hold. ${ }^{5}$ As Guy Peters has put it, 'the real danger is that governance becomes meaningless and a tautology; something happened and therefore governance occurred' ${ }^{6}$ Like to neoliberalism - another highly disputed

\footnotetext{
${ }^{3}$ Luc Boltanski and Ėve Chiapello, The New Spirit of Capitalism (London: Verso, 2007).

${ }^{4}$ For larger edited volumes and introductions of significance, see Mark Bevir (ed), The Sage Handbook of Governance (London: Sage, 2011); and Mark Bevir (ed), The Encyclopaedia of Governance, 2 vol (London: Sage, 2006); as well as David Levi-Faur, The Oxford Handbook of Governance (Oxford: Oxford University Press, 2012); and Anne Mette Kjaer, Governance (Cambridge: Polity, 2004). For some major accounts that have informed debates, see in particular, Rod Rhodes, Understanding Governance: Policy Networks, Governance, Reflexivity, and Accountability (Buckingham: Open University Press, 1997); Gerry Stoker, 'Governance as Theory: Five Propositions', International Social Science Journal, 50, 155 (1998), 17-28; and Kees Van Kersbergen and Frans Van Waarden, "'Governance" as a Bridge Between Disciplines: Cross-disciplinary Inspiration Regarding Shifts in Governance and Problems of Governability, Accountability and Legitimacy', European Journal of Political Research, 43 (2004), 2, 143-171.

${ }^{5}$ The notion of conceptual stretching is derived from Sartori Giovanni, 'Concept Misformation in Comparative Politics', American Political Science Review, 64 (1970), 4, 1033-1053.

${ }^{6}$ Guy Peters, 'Globalization, Institutions, and Governance', in Guy Peters and Donald J. Savoie (eds), Governance in the Twenty-first Century: Revitalizing the Public Service (Buffalo: McGill-Queen's University Press, 2000), 35.
} 
notion - governance is a kind of 'rascal concept', 'promiscuously pervasive, yet inconsistently defined, empirically imprecise and frequently contested'. ${ }^{7}$ As a baseline, the term continues to be compared to government, either as an alternative or complementary conceptual lens. Stemming from this initial position, authors and policymakers who invoke governance often claim that authority today does not only reside with the Leviathan but, instead, is diffused among a variety of actors, operating across a range of social levels and spaces. Analysts have subsequently argued how arrangements called 'governance' help to account for a 'fragmented and multidimensional order within the state, by the state, without the state, and beyond the state'. ${ }^{8}$ In particular, the term often appears as a way to explain major shifts in the location or form of politics, such as from the state to markets, from politicians to experts, or from the national to the global. ${ }^{9}$ In this sense, uses of the expression tend to swing between two poles: governance as process (the steering of policymaking) and governance as structure (the institutions of rule).

The popularity of governance undoubtedly stems from how it appears as a zeitgeist; a modern term to encapsulate and, by implication, supposedly clarify the world. However, there is the risk of using the word as a crutch to lean on, rather than an idea to critically inspect, is that particular social histories associated with the concept including those linked to capitalist processes - may be neglected. To argue for an understanding of governance as grounded in capitalist social relations is not, in itself, new. There is a series of research agendas, across several academic fields, which use governance as a framework to analyse the structures, processes and strategies of rule within capitalist democracies. For instance, in debates ignited by the claim that the (Western) state has been 'hollowed out' under the influence of big business, studies have examined the role of corporate actors in the management of public services, and the regulatory capture of particular state agencies and initiatives. ${ }^{10}$ In the international context, other writers are correct to note how the derivatives of 'global governance' and 'good governance' arose in the context of the post-Cold War period and the universalisation of a business-centred vision of political life. ${ }^{11}$ In these senses, therefore, authors have recognised that the discourse on the 'new governance',

\footnotetext{
7 Neil Brenner, Jamie Peck, and Nik Theodore, 'Variegated Neoliberalization: Geographies, Modalities, Pathways', Global Networks, 10 (2010), 2, 182-22, quoted at 184.

8 David Levi-Faur, "From "Big Government" to "Big Governance", in Levi-Faur, The Oxford Handbook of Governance, 1, italics in original.

${ }^{9}$ Ibid.

${ }^{10}$ See Rhodes, Understanding Governance, as well as a revision in Rod Rhodes, 'Understanding Governance: Ten Years On', Organization Studies, 28 (2007), 8, 1243-1264. For the counter-argument that governments have been 'hollowed in' to enhance their capacity, see Stephen Bell and Andrew Hindmoor, Rethinking Governance: The Centrality of the State in Modern Society (Cambridge: Cambridge University Press, 2009). Other 'second wave' accounts include Bob Jessop's conceptualisation of 'metagovernance', that is, how the state is claimed to steer actors and networks within society who, subsequently, do much of the governing themselves, including implementing policies and providing public services. For a summary, see Bob Jessop, 'Metagovernance', in Bevir (ed), The Sage Handbook of Governance.

${ }^{11}$ For instance, see James N. Rosenau 'Governance, Order, and Change in World Politics', in James N. Rosenau and Ernst-Otto Czempiel (eds), Governance Without Government: Order and Change in World Politics (Cambridge: Cambridge University Press, 1992); Thomas G. Weiss, 'Governance, Good Governance and Global Governance: Conceptual and Actual Challenges', Third World Quarterly, 21, 5 (2000), 795-814. Also see, Thomas G. Weiss and Leon Gordenker (eds), NGOs, the UN, and Global Governance (Boulder, CO: Lynne Rienner, 1996); and Rodney Bruce Hall and Thomas J. Biersteker (eds), The Emergence of Private Authority in Global Governance (Cambridge: Cambridge University Press, 2002)
} 
particularly in some of its policy deployments, arose either to define or, more politically, to give credence to certain economic relations.

My argument here is not directly focused on treading through these well-worn debates but, instead, seeks to sharpen the objectification of governance as a policy term in order to understand better how, within certain institutional contexts, it can be treated as an ideological expression of capitalist motivations. This argument shares some affinities with other critics who have also called for the term to be analysed through the prism of ideology. ${ }^{12}$ In particular, Jonathan Davies' work has offered a sensitive Gramscian-inspired account of how the notion of governance is best grasped as a form of neoliberal ideology, particularly in discourses that stress networks as a normative goal of social and political organisation. ${ }^{13}$ In doing so, Davies calls for a different understanding of governance, one that more deftly probes dimensions of power, including coercive acts, rather than assuming that, politics under the ideal type model of 'network governance', will be beneficial for all. Indeed, in a notable critical extension, his analysis seeks to unpick how " "networked" governance institutions look very much like the "modernist" hierarchies they were supposed to replace'. 14 Thus, ideological analysis has the potential to reveal not only the divergences between theoretical or prescriptive claims and the concrete experience of 'governance', but also how political power may be obfuscated through such vocabularies and who benefits from such processes.

This effort to unravel the ideological properties of the concept of governance is best prosecuted through an empirical tracing of the idea. To uncover the genesis of governance does not imply that the meanings initially ascribed to the term remain rigidly set across all subsequent uses (although certain early traces may leave contemporary imprints). The point of a genealogical method is, rather, to guard against the risk of reifying certain concepts from their historical gestation and to reveal how seemingly innocent expressions emerge out of concrete and, often uneven, material struggles. The argument here does not deny that larger theoretical approaches, such as new public management and rational choice approaches, have informed different meanings of governance and, in turn, these have filtered into policymaking agendas. ${ }^{15}$ For instance, the term emerged in reaction to presumed analytical problems in the social sciences, particularly a rejection of overly strict dichotomies, such as public versus private or market versus hierarchy. ${ }^{16}$ My intention is not to offer some exhaustive discussion of these intellectual trends but, rather, to contextualise how the early policy experimentation with the term arose out of

\footnotetext{
${ }^{12}$ For example, see François-Xavier Merrien, 'Governance and Modern Welfare States', International Social Science Journal, 50, (1998), 155, 57-67; Will Leggett, 'The Analytical and Political Limits to 'Interpreting' Governance', British Politics, 6 (2011), 2, 241-251; Massimo De Angelis, 'The Political Economy of Global Neoliberal Governance', Review (Fernand Braudel Center), 28 (2005), 3, 229-257; and Boaventura de Sousa Santos, 'Governance: Between Myth and Reality', Revista Crítica de Ciências Sociais Annual Review, no. 0, online since September 2009. This critique of governance as a term is also partly inspired by Pierre Bourdieu and Loïc Wacquant, 'NewLiberalSpeak: Notes on the New Planetary Vulgate', Radical Philosophy, January-February, 2001 (105), 2-5.

13 Jonathan Davies, Challenging Governance Theory: From Networks to Hegemony (Bristol: The Policy Press, 2011).

${ }^{14}$ Ibid., 3.

${ }^{15}$ Mark Bevir, Democratic Governance (Princeton: Princeton University Press, 2010).

16 Bob Jessop, 'The Rise of Governance and the Risks of Failure: The Case of Economic Development', International Social Science Journal, 50 (1998), 155, 29-45.
} 
particular problems in the legitimation of capitalist processes. The empirical focus is on revealing illustrations of how institutions tested the potential of the concept but, at the same time, I try to connect and explain such labour in relation to larger material and political forces. In doing so, the empirical stories help to clarify further how governance moved from being an arbitrary or curious expression to something that was considered politically valuable in the management of power.

\section{PROPERTIES OF THE SPIRIT OF CAPITALISM}

Capitalism has historically required reasons for encouraging people to commit to accumulation processes that, in many cases, may be uninspiring, unpleasant or even dangerous. In Marxist and Gramscian analysis, ideology has served as the major conceptual lens to analyse such practices, often depicted as an elite-led 'veiling' instrument which aims to secure the legitimation of an established order. From this perspective, the emphasis is placed on how methods of legitimation are used by capitalists and state officials to maintain particular social relations and how conflict is minimized or 'masked' through seemingly consensual means. ${ }^{17}$ The Marxist study of ideology has long been associated with questions of truth and falsehood, in particular, the impediments (both deliberate and unintentional) that are placed in the pathway of recognising or realising truth. ${ }^{18}$ Other major theorists have also addressed similar themes. For instance, borrowing from Marx and Parsons, Habermas argues that legitimacy is a kind of façade or screen which is necessary for a stable social order, particularly in terms of managing the tensions between capitalism and democracy. ${ }^{19}$ Likewise, Bourdieu, inspired by Weber, developed the notion of symbolic power to explore how the normalisation of authority, including economic agendas, can become absorbed into the cognitive frameworks of both the dominant and the dominated. ${ }^{20}$

The larger conceptual framework in this article stems from these long-standing enquiries. A specific inspiration here comes from Boltanski and Chiapello's The New Spirit of Capitalism (2007), a work which dissects a series of French management texts in order to elucidate the processes through which neoliberalism, conceived as the current stage of capitalism, has sustained itself through the selective distortion of social critiques derived from the 1960s and 1970s. ${ }^{21}$ The title of the book is a nod to the classic Weberian proposition that capitalism requires a particular 'spirit', or set of ideological practices, in order to inspire and motivate capitalists. Their conception of ideology - which I share - is important to clarify. Boltanski and Chiapello depart from the reductionist Marxist sense of the 'dominant ideology', a presumed coherent 'system' engineered by Machiavellian elites in order to conceal material interests. Instead, ideology is theorised as a practical set of relatively stable schemas, grounded in lived experiences, and cultivated by many players including, but also beyond, a

\footnotetext{
${ }^{17}$ Karl Marx and Friedrich Engels, The German Ideology (London: Lawrence and Wishart, 1970); and Antonio Gramsci, Selections from the Prison Notebooks (London: Lawrence and Wishart, 1971).

18 Michael Freeden, Ideologies and Political Theory: A Conceptual Approach (Oxford: Oxford University Press, 1996).

${ }^{19}$ Jürgen Habermas, Legitimation Crisis (Cambridge: Polity Press, 1988).

${ }^{20}$ Pierre Bourdieu, Language and Symbolic Power (Cambridge: Polity Press, 1991); and The Social Structures of the Economy (Cambridge: Polity Press, 2005).

21 Boltanski and Chiapello, The New Spirit of Capitalism. The book draws upon some earlier arguments contained in Luc Boltanski and Laurent Thévenot, On Justification: Economies of Worth (Princeton: Princeton University Press, 2006).
} 
privileged elite. When effectively sedimented and reproduced within institutions and mental structures, these beliefs offer agents stimuli to action, depending upon how the actual justification for action corresponds with the internal dispositions acquired through history.

Among the many interesting arguments developed by Boltanski and Chiapello, they underscore how each ethos of capitalism works not only to stimulate new strategies of profit generation, but also contains ideas that, in part, constrain accumulation processes. ${ }^{22}$ Indeed, they propose that the degree to which the system is legitimised is intimately associated with how constraints are imposed on capitalist behaviour. ${ }^{23}$ Again, in this sense, Boltanski and Chiapello's argument runs counter to the cruder Marxist depiction of ideology as some imposing regime and, instead, proposes that critique serves as a major 'motor of change' in capitalism. ${ }^{24}$ In some cases, this relationship between critique and capitalism can have a relatively clear causal connection, such as a street protest that generates a government policy change. At other times, however, the ties between critique and capitalism are labyrinthine and unstable, particularly if the relations cross time and territories. Overall, they argue that critique is important to study for at least two reasons: not only does it confront capitalism with troubling ethical questions but also, through a period of reflection, experimentation and potential incorporation, critique may inadvertently 'give' new ideological resources to reinvigorate capitalism (or, rather, capitalism 'captures' and claims new ideas for itself). ${ }^{25}$

A key analytical problem for Boltanski and Chiapello is to explain how each spirit of capitalism becomes concretised into organisational practices that guide social actors and provide a sense of meaning to their working lives. Organised theoretical bodies, as found within neoclassical economics for instance, offer a set of stable ideas for modelling capitalism, but they remain too abstract for motivating most workers, including even professionals educated in economic science. To complement such intellectual resources, they suggest that three practical ideological dimensions play an important role. First, capitalism has to offer forms of security for those who are involved in the business of commodification, both for the present and next generation. In the previous spirit of capitalism, which ran from the 1940s to 1970s, security was founded upon large hierarchical firms that offered a degree of job protection and predictable career pathways. Within advanced industrial societies, meanings of security were also shaped by the growth of the welfare state which constructed new safety nets for less privileged groups. In the neoliberal spirit of capitalism, Boltanski and Chiapello argue that security has been redefined to benefit those who are mobile and able to self-manage (the 'entrepreneurial' desire). What is rejected in the current spirit are authoritarian methods of management, excessive bureaucracy, and the separation between one's private and professional lives.

A second set of arguments surround the idea of fairness. In opposition to some theorists who separate capitalism from morality or suppress questions of justice, Boltanski and Chiapello underscore how the legitimation of the system is predicated upon complex appeals to the common good and a sense of community. In the

\footnotetext{
${ }^{22}$ Boltanski and Chiapello, The New Spirit of Capitalism, for instance, 24-27.

23 Ibid., xx.

24 Ibid., xx-xxi.

${ }^{25}$ Ibid., for instance, 27-30.
} 
neoliberal workplace, the fairness dimension is often paired with a security argument: new forms of meritocracy stress the potential to develop one's own 'vision' through social networks and flexible project management. Again, hierarchical modes of rule, through which orders are dictated by a single boss, are considered passé and incompatible with modern business practices. According to this framework, organisations are supposed to be transparent in their communications and capable of negotiating with different societal actors, including those who are presumed to be confrontational, a practice codified through the expansion of corporate social responsibility. A third dimension of the spirit of capitalism is how it appeals to emotionally exciting activities, a quality which has become significant in light of the expansion in consumerism over the post-war period. The arguments offered here tend to revolve around notions of liberation, with particular appeals to innovation and creativity as sought-after drivers of capitalist growth. ${ }^{26}$

Through two pertinent empirical stories below, my argument situates the conceptual birth of governance in light of the unsteady development of a broader neoliberal spirit of capitalism. Specific attention is directed to explaining how the legitimation of the concept can be understood through arguments that have some deeper rationale linked to principles of security or fairness (the emotion of excitement being less relevant for this particular concept). These principles do not always need to be clearly articulated and reasoned; indeed, it is often politically useful for lines of responsibility to remain blurred and ambiguous. To underscore again, this explanatory exercise is not meant to encapsulate some 'essential truth' of governance that can be applied to all social environments. While my argument does aim to illuminate how governance now occupies a central place in the vocabulary of neoliberalism, this does not imply that the term is only used in contexts that have some appeal to commodification processes. ${ }^{27}$ By arguing that governance is part of a particular vocabulary, I am also trying to explain how this difficult term is situated in a conceptual organising grid; that is, how the vague and often confusing meanings of the word only make sense in relation to other 'core' and 'peripheral' notions within a larger body of thought, such as 'partnership', 'empowerment' and 'network' ${ }^{28}$ At the same time, one also needs to appreciate that discrepancies may exist between, on the one hand, abstract aspirations for a neoliberal spirit and, on the other, how material relations are concretely realised in particular social and spatial settings. What could be called the 'operative ideology' of 'actually existing neoliberalism' - the ideas that are embedded into organisational rules, codes, and behavioural practices - may only be a partial or distorted realisation of some 'theoretical ideology' of neoliberalism. ${ }^{29}$

\section{THE CORPORATE ROOTS OF 'GOVERNANCE'}

Despite its modern appearance, governance is actually a very old term which has long been associated with discipline and the action or manner of governing. This history of the concept, dating back to medieval usages, is not the centre of attention in this

\footnotetext{
${ }^{26}$ Ibid., for instance, 12-16.

${ }^{27}$ Matthew Eagleton-Pierce, Neoliberalism: The Key Concepts (Abingdon: Routledge, 2014).

28 The metaphors of core and periphery in this context are derived from Freeden, Ideologies and Political Theory: A Conceptual Approach.

${ }^{29}$ Loïc Wacquant, 'Three Steps to a Historical Anthropology of Actually Existing Neoliberalism', Social Anthropology, 20 (2012), 1, 66-79.
} 
paper. But it is interesting to note how some authors who have struggled with the term have reached for their dictionary to draw upon these older senses. One finds that governance entered English in the fourteenth century (derived from the French governaunce) and was used by Chaucer in reference to both political and personal affairs. ${ }^{30}$ The word could refer to the rule over a territory or the command of a military force, particularly in nautical contexts, to define practices of steering and directing (from the Latin guberno). At the same time, governance also meant general administrative control, not confined therefore to states but also applied to control within the household. ${ }^{31}$ Thus, the expression appears to have an initial origin in changing expectations of human behaviour and, in particular, the idea of being condemned if a person did not reach some ideal standard of comportment. ${ }^{32}$

Some of these meanings that were attached to the term have not been lost in its recent usage. Indeed, the sense of governance as being about steering and directing has been applied to contemporary contexts. For instance, thinking of the nautical history, one can note how some authors who use the term argue for governments 'to steer' the macro forces of society and leave other actors, including business players, 'to row'. 33 However, when one advances the analytical focus to the twentieth century, where are the political and social seeds of its explicit revival and re-reading? I would suggest, in the first instance, that governance was retrieved not in the immediate context of the post-Cold War period, nor in reaction to some codified neoliberal revolution in policymaking from above which accelerated during the 1990s. Rather, I argue here that the term emerges in light of the perceived crisis of governability within Western societies during the 1970s or, to locate it more specifically, the 'Anglophone heartland'. ${ }^{34}$ This early context is grasped by some authors, such as Mark Bevir's attention to the strains experienced by forms of bureaucratic rule associated with the Westminster model of politics. ${ }^{35}$ What is still lacking, however, is a more studied exploration of the initial experimentation with the precise term 'governance' and how, in particular, its uses are informed by broader trends in the culture of capitalism.

According to some observers at this time, the economic and cultural changes of the 1970s - from stagnation and oil crises to the fallout from Vietnam and Watergate were leading to conditions of 'political bankruptcy'. ${ }^{36}$ Within the US in particular, there were fears by many astute defenders of the market system that social cohesion

\footnotetext{
${ }^{30}$ The Shorter Oxford English Dictionary on Historical Principles, C.T. Onions (ed), (Oxford: Clarendon Press, 1933); and Christopher Cannon, The Making of Chaucer's English: A Study of Words (Cambridge: Cambridge University Press, 1998).

${ }^{31}$ Middle English Dictionary (Ann Arbor: University of Michigan Press), last updated December 18, 2001, http://ets.umdl.umich.edu/m/med.

32 Barbara A. Hanawalt, "Good Governance" in the Medieval and Early Modern Context', The Journal of British Studies, 37 (1998), 3, 246-257.

33 David Osborne and Ted Gaebler, Reinventing Government: How the Entrepreneurial Spirit is Transforming the Public Sector (Reading: MA: Addison-Wesley, 1992).

${ }^{34}$ Kees van der Pijl, 'A Lockean Europe?', New Left Review, 37, January-February, 2006. Until the 1970 s, the word does not appear to have been very popular. For instance, in a search of publications at the British Library for the period 1900-1969, only 41 items return 'governance' in the title. Indeed, in one edition of the Chambers Twentieth Century Dictionary (Edinburgh: Chambers, 1972), the expression was defined as obsolete.

${ }^{35}$ Bevir, Democratic Governance.

${ }^{36}$ Richard Rose and Guy Peters, Can Government Go Bankrupt? (London: Macmillan, 1978). In Boaventura de Sousa Santos' article, 'Governance: Between Myth and Reality', this same historical context is also recounted to explain the rise of the term.
} 
was fragmenting. A report by the Trilateral Commission in 1975 provides an illuminating (and somewhat paranoid) insight into the mind of conservative thinking. ${ }^{37}$ According to Commissioner Samuel P. Huntington and his associates, certain modes of government were giving rise 'to forces and tendencies which, if unchecked by some outside agency, will eventually lead to the undermining of democracy'. They concluded that the 'democratic surge' was to blame for generating 'a breakdown of traditional means of social control, a de-legitimation of political and other forms of authority, and an overload of demands on government, exceeding its capacity to respond'. ${ }^{38}$ Even in that conservative Western club, the OECD in Paris, employment experts were speculating about the trajectory of social unrest. Some actually used the term 'revolution' to describe what they thought was (or could be) going on outside their offices on the streets. They complained repeatedly about a 'general challenge to authority'. ${ }^{39}$

It is in this volatile environment, complete with a range of social and political demands, that the word governance reappears. Initially, the first people who began thinking about the term and elaborating upon its meaning were those who were confronting a legitimacy deficit in a vital institution: the American corporation. The attachment of 'corporate' to 'governance' was a response to different forces and trends, but of chief significance were 'consumer-orientated politics', demands for increased shareholder power, and open business reporting. ${ }^{40}$ The behaviour of leading managers intersected with all these concerns. It is important to recall that during this period the public image of the US corporation was greatly damaged as a result of revelations of executive misbehaviour and unruliness, investigated with particular zeal by Ralph Nader and his contemporaries (the closest activists referred to as 'Nader's Raiders'). ${ }^{41}$ Consumer safety concerns at General Motors were one prominent example. Other criticisms surrounded reports of illicit payments made by US firms to foreign government officials, notably the Lockheed bribery scandal that

\footnotetext{
${ }^{37}$ Trilateral Commision, The Crisis of Democracy: Report on the Governability of Democracies to the Trilateral Commission (New York: New York University, 1975), 8.

${ }^{38}$ Ibid. In the most abstract sense, forms of politics associated with neoliberalism arose in reaction to the crisis of governability, although intellectual seeds existed earlier, such as with the Colloque Lippman in Paris in 1938 and the 'thought collective' anchored by the Mont Pèlerin Society after 1947. See Philip Mirowski and Dieter Plehwe (eds), The Road from Mont Pèlerin: The Making of the Neoliberal Thought Collective (Harvard: Harvard University Press, 2009). In the 1970s, within leading governments such as the US and UK, a critique of Keynesian economic policies was combined with a generalised suspicion of collective models of social and political organisation. The need to reassert the legitimacy of corporate practices interlaced with such concerns. For the most careful historical exploration of neoliberalism, including the difficulty of defining what 'has always been an open-ended, plural and adaptable project', see Jamie Peck, Constructions of Neoliberal Reason (Oxford: Oxford University Press, 2010), 3.

${ }^{39}$ OECD, Les nouvelles attitudes et motivations des travailleurs, Direction de la main-d'oeuvre et des affaires sociales (Paris: OECD, 1972). Employment experts from OECD countries were particularly concerned about the increased frequency of strikes in France, Italy, Germany, and the UK.

${ }^{40}$ See an early discussion in Neil H. Jacoby, Corporate Power and Social Responsibility: A Blueprint for the Future (New York: MacMillan, 1973). For an overview of the rise of the term, but with a theoretical context not adopted in this article, see Brian R. Cheffins, 'The History of Corporate Governance', in Mike Wright, Donald S. Siegel, Kevin Keasey, and Igor Filatotchev (eds), The Oxford Handbook of Corporate Governance (Oxford: Oxford University Press, 2013). For a neo-Marxist reading, see Susanne Soederberg, Corporate Power and Ownership in Contemporary Capitalism: The Politics of Resistance and Domination (Abingdon: Routledge, 2010).

${ }^{41}$ Ralph Nader, Mark Green, and Joel Seligman, Taming the Giant Corporation (New York: W.W. Norton, 1976).
} 
led to considerable political controversy and almost destroyed the company. ${ }^{42}$ Through the establishment of Public Citizen, his consumer rights advocacy group, Nader secured a prominent platform to promote his vision of the federal chartering of US companies. ${ }^{43}$ In short, the wider crisis of governability was bound up with a particular corporate legitimation problem.

In an article which reinforces my argument, William Ocasio and John Joseph propose that Nader deserves primary credit for promoting an analogy between the governance of democracy and the governance of the corporation. ${ }^{44}$ By 1976 , encouraged by Nader's corporate accountability studies, the US Senate Committee on Commerce hosted a set of hearings on 'Corporate Rights and Responsibilities'. The term 'governance' was invoked in one session by Richard M. Cyert, then Dean of Carnegie Mellon University, who used it to comment on the relationship between chief executive officers, corporate boards, and shareholders. By the end of 1976, in the Federal Register, the US government journal, the phrase 'corporate governance' was used for the first time in an official document. The term was noted in connection with an emerging study being conducted by the US Securities and Exchange Commission (SEC) which was to explore 'shareholder participation in corporate governance and, more generally, shareholder democracy'. ${ }^{45}$ Elsewhere, by the late-1970s, in a series of symposiums, the American Law Institute (ALI) and the American Bar Association began to react to what was being called 'the erosion doctrine'. ${ }^{46}$ Out of these meetings came the decision of the ALI to establish an initiative which would investigate what 'corporate governance' actually meant and how it could be legally defined. ${ }^{47}$ Initially viewed as controversial by some, the ALI Corporate Governance Project was born to address this erosion of legitimacy, in particular to control those insatiable managers who were straying too far from some ideal behavioural model. As the 1980s unfolded, the corporate governance literature flourished. Every top firm dispatched their leading counsel to the annual meetings of the ALI in order to shape the new meanings of the term. By uttering the word 'governance' one could show to others - both critics and sympathisers - that one was being proactive in acknowledging the need for 'business reforms' or, just simply, 'reforms'.

Not unlike other later periods when corporate scandals were politically hot, such as around the collapse of Enron in 2001 and the fallout from the present banking crisis, I would argue that the word governance became intuitively useful because it implied that the American firm needed closer surveillance and discipline. The vagueness of the expression did not detract from its social value, particularly in terms of communicating with multiple audiences. Indeed, like any good frame, it offered a flexible mental short-cut that could be used to distil information, shape

\footnotetext{
${ }^{42}$ Joel Seligman, The Transformation of Wall Street: A History of the Securities and Exchange Commission and Modern Corporate Finance (Boston: Houghton Mifflin, 1982).

${ }^{43}$ Ralph Nader, Mark J. Green, and Joel Seligman, Constitutionalizing the Corporation: The Case for the Federal Chartering of Giant Corporations (Washington D.C.: Corporate Accountability Research Group, 1976).

${ }^{44}$ William Ocasio and John Joseph, 'Cultural Adaptation and Institutional Change: The Evolution of Vocabularies of Corporate Governance, 1972-2003', Poetics, 33 (2005), 3-4, 163-178.

${ }^{45}$ Ibid., 167.

${ }^{46}$ Walter Werner, 'Corporation Law in Search of Its Future', Columbia Law Review, 81 (1981), 8, 1611- 1666, quoted at 1613.

${ }^{47}$ Donald E. Schwartz (ed.), Commentaries on Corporate Structure and Governance (Philadelphia: ALI- ABI, 1979).
} 
understandings on problems and, in keeping with my general argument here, encourage action. ${ }^{48}$ At a deeper, almost pre-reflexive level, the agenda under corporate governance 'made sense' in relation to the enduring normative demands for fairness and security in the justification of capitalism. The watchword of governance enabled an organisation of debates for the purpose of reining in corporate abuses. At the very least, the appeal to corporate governance highlighted the question of elite power and responsibility for perceived injustices (to whom and under what conditions remained unclear). Importantly, this corporate governance agenda was inspired by an external critique and, thus, offers an empirical illustration of Boltanski and Chiapello's larger argument that the emerging neoliberal spirit in the 1970s and 1980s 'looked outside' core capitalist institutions for inspiration on how not only to enable new accumulation processes but also constrain excessive business practices that were jeopardising the broader legitimation of capitalism.

\section{THE TRANSNATIONAL DISSEMINATION OF 'GOVERNANCE'}

By the 1980s, the word governance began to spread from the corporate arena to the broader political field. These processes of diffusion and appropriation are difficult to map and tend to resist easy summation. However, one can elaborate upon one particular conceptual articulation of governance which has proved significant, not least because it had transnational implications. It centres on how the World Bank - an institution historically sensitive to domestic political debates in Washington D.C. theoretically grappled with the notion. Like the refining of the term in corporate law and management theory, the idea of governance came to the Bank in response to a critique. The roots of the concept are found, in the first place, with the early resistance to the implementation of policies associated with neoliberalism in Southern countries. In this sense, we move from the original conditions which inspired the use of the term - the crisis of governability - to a second source: the resistance to the neoliberal counter-revolution that was, in part, inspired by the 1970s crisis. As with the genesis of the corporate governance discourse, I highlight the value of Boltanski and Chiapello's interpretation of the links between critique, justificatory terms, and new strategies of capitalist accumulation.

The World Bank is a relatively transparent site of legitimation in the 'international development industry'. Broadly speaking, the institution is tasked with organising ideas on the meaning and practice of development, as well as dispersing a variety of loans, credits and grants to Southern countries. ${ }^{49}$ The Bank was an early adopter of the term governance and, as a consequence of its dominant institutional position, has strongly informed how the expression has been understood, both in the development policy world and the academy. The concept was born out of criticism of structural adjustment policies (SAPs) pursued in many African and Latin American countries. In the early $1980 \mathrm{~s}$, SAPs were ostensibly introduced by the Bank, in cooperation with the International Monetary Fund (IMF), to meet the problem of the third world debt crisis. In return for emergency loans, a common SAP formula would include general

\footnotetext{
${ }^{48}$ Erving Goffman, Frame Analysis: An Essay on the Organization of Experience (New York: Harper \& Row, 1974).

49 For initial introductions, see Katherine Marshall, The World Bank: From Reconstruction to Development to Equity (Abingdon: Routledge, 2008); and Ngaire Woods, The Globalizers: The IMF, the World Bank, and Their Borrowers (Ithaca: Cornell University Press, 2006).
} 
cuts to state expenditure, devaluation of the currency, increased trade liberalisation at the border, and privatisation of state agencies. Yet, as even a cursory glance of the results of these programs illustrated, no economic project (conceptually bracketed as 'divorced' from politics) was likely to be sustainable unless minimum conditions of state legitimacy, social order, and institutional capacity were present. ${ }^{50}$ The critics - to be found within Southern government ministries, on the streets of major cities and, a little later, within the Northern academy and civil society groups - began arguing that the state had been unnecessarily 'hollowed out', that this impeded the development process, and that such conditions were caused by Bank policy prescriptions. The economy was embedded in society, they claimed, not the other way around. Above all, these critics argued that the Bank advanced such dictates in a top-down fashion that left little room for government agency. ${ }^{51}$

In this context, the 1989 Bank report, Sub-Saharan Africa: From Crisis to Sustainable Growth, should be read as an 'official' reaction to this growing legitimacy problem. For the first time in a public document, the word governance was mentioned, in relation to a 'crisis' which was linked to the 'litany of Africa's development problems'. ${ }^{52}$ Shrouded in orthodox commonplaces, it was difficult to decipher if the Bank believed that its own actions had in any way caused or perpetuated such problems. ${ }^{53}$ But the report's authors were adamant on one matter: 'political legitimacy and consensus' were not after-thoughts in the process of sustainable development, but 'preconditions'. What was needed in the space of Sub-Saharan Africa, they argued, was 'political renewal' and the creation of a 'pluralistic institutional structure'. ${ }^{54}$ In short, governance was defined in this context as 'the exercise of political power'. ${ }^{5}$ But how did this talk fit with the Bank's Articles of Agreement which officially forbid it from 'doing politics'? At this point, the Bank did not have any easy or predictable answers because it had yet to clarify conceptually the term in its own institutional (hydra) head. Thus, if governance was to become a new received idea, the most sensitive experts knew that it would be wise to check with the lawyers first.

In this regard, the Bank's General Counsel, Ibrahim Shihata, played a very important role in expounding and codifying what governance could entail. In a long and

\footnotetext{
${ }^{50}$ For introductions to the form and consequences of SAPs, see Ed Brown, Bob Milward, Giles Mohan, Alfred B. Zack-Williams (eds), Structural Adjustment: Theory, Practice and Impacts (London: Routledge, 2000); and Structural Adjustment Participatory Review International Network (SAPRIN), Structural Adjustment: The SAPRI Report: The Policy Roots of Economic Crisis, Poverty and Inequality (London: Zed Books, 2004).

51 Examples of forms of criticism that Bank officials would have recognised included the opposition to SAPs by African states in the Abuja Declaration (1987) and the Khartoum Declaration (1988); frequent episodes of social protest and mobilisation by workers in many countries ('the IMF riots'); the prominent activism of US-based environmental groups, such as the Environmental Defense Fund (as explored by Robert Wade); and important policy-relevant publications, such as Giovanni Andrea Cornia, Richard Jolly, Frances Stewart (eds), Adjustment with a Human Face: Volume I: Protecting the Vulnerable and Promoting Growth (Oxford: Oxford University Press, 1987). I thank Alastair Fraser for guidance on these sources.

52 World Bank, Sub-Saharan Africa: From Crisis to Sustainable Growth: A Long-Term Perspective Study (Washington D.C.: World Bank, 1989), 60.

${ }^{53}$ The Bank was careful not to sell every SAP in every country as a success story. At times it noted that it may have been 'too optimistic' about the capacity of governments to implement its dictates. See World Bank, Interim Report on Adjustment Lending (Washington D.C., World Bank, 1988).

${ }^{54}$ World Bank, Sub-Saharan Africa: From Crisis to Sustainable Growth, 6, 61.

${ }^{55}$ Ibid., 60. Italics added.
} 
carefully justified statement to the Executive Directors in 1991, he argued that " "governance," in the sense of good order and discipline in the management of a country's resources, is a relevant matter for the Bank's activities' ${ }^{56}$ But clarification was certainly needed, as Shihata expressed it, above all because 'perceptions, coupled at times with vague statements, within and outside the Bank, have tended to give the impression that all issues of governance in borrowing countries may have become part and parcel of the Bank's concern, if not its direct business'. ${ }^{57}$ As a consequence, his initial formulation was still very tentative when compared to where the Bank would later take the term. Shihata argued that governance was being studied and shaped if it involved areas such as civil service, legal and administrative 'reform', as long as such programs could be linked to 'economic development', the Bank's core remit. The notion was helpful at this point in terms of managing the tense (and supposedly dichotomous) relationship between what was called 'economic' affairs and what was considered the domain of 'politics'. Thus, to put it another way, one could argue that Shihata, as the Bank's 'chief consecrator', was searching for the means to build the symbolic power of governance (to make it a recognisable 'universal' term), but this could only begin by drawing upon the existing legitimacy found in the Bank's older categories, classifications, and missions. ${ }^{58}$

Following this reshaping of what was deemed legitimate, however, other analysts had a freer hand to evaluate and re-evaluate the term. ${ }^{59}$ Very quickly, many of these experts sensed how governance could be extremely valuable, both 'discursively and programmatically'. ${ }^{60}$ With the Cold War over, the word began to spread rapidly as a 'planetary vulgate'; its original conditions of production and signification becoming further obfuscated. ${ }^{61}$ By 1996, under the direction of James Wolfensohn at the Bank, the term came to be associated with the rule of law, state effectiveness and, in particular, controlling corruption. Bt the turn of the century, another three 'dimensions' had been added under the same rubric: voice and accountability, political stability and the absence of violence, and regulatory quality. ${ }^{62}$ In recent years, the Bank has settled on these six categories and has become keen to demonstrate that this nebulous concept - which is presently summarised as the

\footnotetext{
${ }^{56}$ Ibrahim Shihata, 'Issues of "Governance" in Borrowing Members - The Extent of Their Relevance Under the Bank's Articles of Agreement', in Ibrahim Shihata, The World Bank Legal Papers (The Hague: Martinus Nijhoff, 2000), 247. The legal memorandum was originally submitted by Shihata to the Executive Directors on April 11, 1991. Italics added.

${ }^{57}$ Ibid., 254.

${ }^{58}$ Pierre Bourdieu, The State Nobility: Elite Schools in the Field of Power (Cambridge: Polity Press, 1996).

${ }^{59}$ For example, in 1991 the Bank devoted part of its Annual Development Economics Conference to the theme of 'good governance'. This was later followed by the publication of World Bank, Governance and Development (Washington D.C.: World Bank, 1992); as well as important interventions by Pierre Landell-Mills, Senior Policy Advisor for Africa. See Pierre Landell-Mills, 'Governance, Cultural Change, and Empowerment', The Journal of Modern African Studies, 30, 4 (1992), 543-567.

${ }^{60}$ Graham Harrison, The World Bank and Africa: The Construction of Governance States (London: Routledge, 2004), 4. Also see, in particular, Catherine Weaver, Hypocrisy Trap: The World Bank and the Poverty of Reform (Princeton: Princeton University Press, 2008) and, more generally, Rita Abrahamsen, Disciplining Democracy: Development Discourse and Good Government in Africa (London: Zed Books, 2000); and David Craig and Doug Porter, Development Beyond Neoliberalism?: Governance, Poverty Reduction and Political Economy (Abingdon: Routledge, 2006).

${ }^{61}$ Bourdieu and Wacquant, 'NewLiberalSpeak: Notes on the New Planetary Vulgate'.

${ }^{62}$ See Daniel Kaufmann, Aart Kraay, and Massimo Mastruzzi, Governance Matters VI: Governance Indicators for 1996-2006, July 2007 (Washington D.C., World Bank, July 2007).
} 
'traditions and institutions by which authority in a country is exercised' - can be ordered and refined. ${ }^{63}$ Promoting governance now means '[e]nabling the country to be in the driver's seat', a process that 'requires strong partnership among the executive branch of government, other levels of government, the legislature, local authorities, civil society, the private sector, donors, international agencies, and other development actors' ${ }^{64}$ Or, in another light, governance from the Bank's position can (or should) be ambiguous, but not too ambiguous. To this end, the establishment of the Worldwide Governance Indicators project, complete with country rankings on who is up and down in the 'governance' stakes, can be read as one of the organisation's major symbolic tools for managing the flexibility found (and constructed) in the word. ${ }^{65}$

At first glance, it might appear that Boltanski and Chiapello's framework, formulated in the context of business management, would be less applicable for understanding the governance agenda of the Bank. However, I would suggest that their insights can, at a higher level of abstraction, also enlighten this story. First, social and political critique, emanating from different sources, was the initial motor of change that triggered a re-evaluation on how the Bank conceived and prosecuted lending policy in indebted countries. The appeal to governance - tentatively grasped at first, before expanding to embrace many other facets of state restructuring - could be defined as an effort to 'tighten up' the 'tests of justification' as Boltanski and Chiapello would express it (to improve the fairness of the test). ${ }^{66}$ For instance, one 'test' within this governance agenda has been how trade theory, previously articulated in a hubristically confident manner by Bank technicians in the 1980s, is now expressed more cautiously, especially in terms of the empirical linkages between industrial organisation, domestic institutions, and the so-called 'sequencing of reforms'. ${ }^{67}$ In relation to this particular problem, the neoliberal spirit has now replenished its legitimacy, through countless policy and academic exchanges, both within and beyond the Bank, to incorporate a response to the original critique that external trade opening, without adequate conditions, was potentially damaging for such countries. In doing so, the test has been made 'stricter' in order 'to make it more consonant with the model of justice that supports judgements claiming legitimacy'. ${ }^{68}$ Governance was a linchpin concept within a larger neoliberal vocabulary of ideas that assisted in this corrective legitimation process.

Second, the Bank's use of governance as a framing device, particularly around the 'good governance' derivative in donor-recipient negotiations, appears to resonate with a more widespread desire for political concepts that emphasise partnerships and

\footnotetext{
${ }^{63}$ World Bank, Governance and Anti-Corruption, 'What is Our Approach to Governance?', $<$ http://web.worldbank.org $>$.

${ }^{64}$ Such arguments were latter distilled into the Bank's 'Principles of the Comprehensive Development Framework'. See World Bank, Principles of the Comprehensive Development Framework: A Synthesis Report (Washington D.C., World Bank, 2003), 71.

${ }^{65}$ World Bank, Governance Matters 2007; Worldwide Governance Indicators 1996-2006.

${ }^{66}$ Boltanski and Chiapello, The New Spirit of Capitalism, 495.

${ }^{67}$ On debating the role of trade relative to other economic reforms, see the OECD's work in particular, including Patrick Love and Ralph G. Lattimore, International Trade: Free, Fair, and Open? (Paris: Organisation for Economic Co-operation and Development, 2009). More generally, see the argument that the 'Washington Consensus' has now been 'augmented' through attention to issues of institutions and 'governance' in Dani Rodrik, 'Goodbye Washington Consensus, Hello Washington Confusion? A Review of the World Bank's Economic Growth in the 1990s: Learning from a Decade of Reform', Journal of Economic Literature, 44 (2006), 4, 973-987.

${ }^{68}$ Boltanski and Chiapello, The New Spirit of Capitalism, 33.
} 
networks over dictation and hierarchies. Admittedly, this point is captured by authors who have debated the notion of governance, but bears further inspection in light of Boltanski and Chiapello's attention to business as a laboratory for rethinking how to control human subjects. As they argue, the spirit of neoliberalism repeatedly entices agents with a normative demand for individualised expression - 'voice' as typically invoked by the Bank - which is implicitly opposed to the presumed command-andcontrol organisational practices in the previous spirit of capitalism. However, as a substantial critical literature has argued, power has not dissolved in fuzzy, postbureaucratic-inspired arrangements of 'good governance'. ${ }^{69}$ On the contrary, forms of bureaucracy - hierarchical appraisal, acquiescence to authority, strict rules and codes, and intimidatory practices - have in many examples not gone anywhere, including at the Bank. Depending upon the empirical context, we may have a political form called 'governance' which looks or is represented as post-bureaucratic, but may in reality to be nothing of the sort, or, alternatively, be something of a hybrid between bureaucracy and post-bureaucracy. In short, one should be alert to how the legitimation of agendas under the heading of 'governance', as with the Bank's policy interventions, may in fact be encouraging or enabling more intense and sophisticated forms of control on the part of already privileged actors.

\section{CONCLUSION}

This article has been preoccupied with explaining the early genesis of the notion of governance in light of larger ideological changes in the culture of capitalism. Although the concept has been debated within different areas of the social sciences, understanding the term through this particular lens has been underexplored. By comparing the roots of corporate governance with the Bank's experimentation with the term, we can draw some concluding remarks. Through applying the Boltanski and Chiapello framework, I have argued how the concept has been adapted to manage problems of legitimacy within relations of power. Thus, governance became a politically valuable word when arguments that constituted the spirit of capitalism 'tests' of its security and justice content in my illustrations - came under renewed scrutiny. The application of the term seems to imply that an entity or process is political, but not overtly political; that it is paradoxically all about power and yet not about power. Given this chameleon-like quality, it is not surprising that the expression has been seized upon by many professionals of politics who seek to evade, expand, or euphemise the 'political' content of their work. As a framing tool to organise agendas,

\footnotetext{
${ }^{69}$ Post-bureaucracy is a concept that has been formulated principally in management studies, organisation studies, and different areas of critical sociology within the past twenty years. The paradigm of the so-called post-bureaucratic organisation contains a lot of claims, but in essence it states that the decentralised, non-hierarchical, fluid organisation is the model now and for the future. Management authors in this literature, such as Tom Peters, claim that this type of organisation operates on the basis of vertical and horizontal networking, mutual collaborative adjustment, and is guided by visions and shared values. The ability of the organisation to enable movement and to empower workers, to give them autonomy and space for creative expression, is a central objective. In turn, it is argued that the mainstreaming of such a model - through connections, communications, and ties of trust - will bring efficiency savings and greater worker satisfaction. See Charles Heckscher and Anne Donnellon (eds), The Post Bureaucratic Organization: New Perspectives on Organizational Change (London: Sage, 1994); Chris Grey and Christina Garsten, 'Trust, Control and Post-Bureaucracy', Organization Studies, 22 (2001), 2, 229-250; and Phil Johnson, Geoffrey Wood, Chris Brewster and Michael Brookes, 'The Rise of Post-Bureaucracy: Theorists' Fancy or Organizational Praxis?', International Sociology, 24 (2009), 1, 37-61.
} 
mobilise diverse agents, and offer some motivational cues, the term governance flits between the intuitive sense of hierarchical ordering (long tied to state rule) and the modern appeal to horizontal networking (expressed as established institutions of power who 'consensually' work with multiple agents on collective problems). Governance thus seems to be a kind of bridging concept between the bureaucratic and post-bureaucratic visions of politics, but normatively it is often used to privilege the latter as the presumed 'high watermark' of policymaking practice.

Seen through this prism, I am not claiming, in a crude path-dependent manner, that all subsequent meanings and uses of governance from the 1990s have carried some 'taint' of capitalism. The concept has now been remoulded and deployed within many contexts that do not have an explicit link to capitalist agendas. That I recognise. Yet the diffusion of the term into these other domains and intellectual agendas also indirectly works to further normalise those uses that are closest to capitalist initiatives. Equally, I am not suggesting that the term governance, within the given examples, magically 'fixed' problems of legitimacy. As suggested, one would need to dissect how this master concept is deriving its legitimating force from other notions in a larger neoliberal vocabulary (positively, as in terms like partnership; or negatively, as in the criticism of hierarchy). ${ }^{70}$ As noted, theoretical bodies, such as neoinstitutional economics and new public management or, more broadly, rationalist methodologies, often help to bolster the conceptual edifice called governance; this is an argument made by other scholars. ${ }^{71}$ The more limited purpose here was not to rehearse the content of these 'governance theories', but to uncover empirically how the expression entered into the language of two prominent institutional fields prior to its popularisation. By using 'governance' as a window to analyse larger forces, my argument has also revealed again, in the tradition initiated by Marx, how capitalism has a regenerative capacity not simply to withstand the roiling waves of social critique but to incorporate - often in a partial and distorted manner - elements of those critiques amenable to new accumulation practices. At the moment of creation, these processes can often appear unpredictable, before realising an apparent coherence over time. Thus, this argument has been about denaturalising the often 'ahistorical' appeal of governance in order to showcase how ideological analysis can reveal something of the constitution, and contestation over, capitalist relations of power.

\footnotetext{
${ }^{70}$ Eagleton-Pierce, Neoliberalism: The Key Concepts.

${ }^{71}$ Bevir, Democratic Governance.
} 